\title{
Yehudah Ben Samuel Halevi: el exilio como redención
}

\section{Samuel Ben Yehudah Halevi: Exile and Redemption}

\author{
Armando López Castro \\ Universidad de León, España \\ alopezcastro49@gmail.com
}

\begin{abstract}
RESUMEN
En la poesía medieval de los judíos españoles, tanto sagrada como profana, late la nostalgia de una patria perdida y salvada por la lengua. Ella es su suelo más firme, la que permite restablecer desde el naufragio de una situación hostil la plenitud de la memoria colectiva. En el caso del poeta tudelano Yehudah Halevi, cuya vida errante le llevó a visitar diversas cortes, Zaragoza, Toledo, Córdoba, Sevilla, Granada, pero sin establecerse definitivamente en ninguna, la experiencia del exilio le permitió sentirse como eje de la historia en medio de las naciones, en vivir con la esperanza de regresar a una tierra identificada con el paraíso. Porque la poesía participa ella misma de este doble movimiento de expulsión y retorno, de salida de lo habitual y de regreso al origen, al punto único en que despierta el sentido de la vida.
\end{abstract}

Palabras Clave: memoria, lengua, paraíso, poesía

\begin{abstract}
In medieval poetry of the Spanish Jews, both sacred and profane, late nostalgia for a lost and saved by the tongue homeland. She is his firmer ground, which can restore from the wreck of a hostile situation the fullness of collective memory. In the case of tudelano poet Judah Halevi, whose wanderings took him to visit different courts, Zaragoza, Toledo, Cordoba, Sevilla, Granada, but without settling permanently in any, the exile experience led him to feel like axis of history among the nations, live with the hope of returning to a land identified with paradise. Because poetry involved herself in this double movement of expulsion and return out put than usual and back source, the only point that awakens the to the meaning of live.
\end{abstract}

KEYWORDS: memory, language, paradise, poetry

FECHA DE RECEPCIÓN: 27/03/2019

FECHA DE ACEPTACIÓN: 24/07/2019

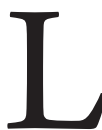

a poesía medieval de los judíos españoles tuvo su mayor florecimiento entre 1090 y 1140 , cuando la pretendida unidad del califato cordobés da paso a la disgregación de los reinos de taifas, sobre todo los de 
Zaragoza y Sevilla, en cuya atmósfera de libertad y tolerancia se produce una estrecha colaboración entre judíos y musulmanes. Los judíos que por entonces ocupaban altos cargos en las cortes, bien como consejeros o médicos de los reyes, consideraban un deber proteger a los sabios de su raza, como sucedió con Yecutiel ibn Hasan en la corte de los reyes tuyibies de Zaragoza, que se convirtió en el mecenas del poeta y filósofo Selomo ibn Gabirol. En lo que a la poesía se refiere, la fidelidad a la tradición bíblica, de la que es buena muestra el tema mesiánico de Sión desolada, se traduce en el cultivo del tono elegíaco y el ritmo paralelístico de la poesía sinagogal. De modo general, puede decirse que tanto en la poesía sagrada, de raíz coral y encomiástica, como en la profana, más diversa e individual, late la nostalgia de una patria perdida y salvada por la lengua. Ella es su suelo más firme, la que permite restablecer desde el naufragio de una situación hostil la plenitud de la memoria colectiva. ${ }^{1}$

Tarea larga y ardua, la de la escritura, entendida como aproximación al nombre de Dios, del que está tejida la Torá, que constituye su explicación y comentario. Por eso, a lo largo de la tradición cabalística, la Torá se identifica con el Nombre divino y ese Nombre es un organismo vivo. Se comprende así que la experiencia del exilio, según el cual el ser ya no se halla en su morada y debe ser reconducido a su lugar de origen, no es sólo cósmica, sino también lingüística, puesto que implica una acción ritual en la que el despliegue del Nombre divino estaría complementada por la reconstitución de sus variantes. En este sentido, ¿no sería el exilio un acto de creación que se constituye por el paso de la unidad a la dispersión y de ésta a la sola unidad? Ir hacia la unidad sería entonces volver a encontrar el orden original, sin el cual no existiría, pues el exilio fue la primera palabra. Sentir la unidad del Verbo en el exilio: tal fue la fuerza del destino judío, cuya inquietud sirve para mantener abierta la diferencia. Esta conciencia de no pertenecer a un lugar determinado fue la que llevó al poeta tudelano a vivir de forma errante, visitando diversas cortes, Zaragoza, Toledo, Córdoba, Sevilla, Granada, pero sin establecerse definitivamente en ninguna de ellas, como si la nostalgia de volver a Tierra Santa le impidiese permanecer en un punto fijo. Esta situación de provisionalidad,

\footnotetext{
${ }^{1}$ Refiriéndose al clima de convivencia durante los reinos de taifas, señala Millás Vallicrosa: "Precisamente nuestros judíos españoles fueron, en general, los grandes iniciadores de los cristianos en temas filosóficos o científicos; fueron ellos los grandes traductores de la cultura científica árabe a las lenguas romances, al hebreo o bien al latín" (Literatura hebraicoespañola, 48-49). Gabirol y Halevi fueron, sin duda, los dos mayores poetas hebraicos durante la Edad Media y los que mejor cultivaron la poesía de tradición sinagogal. En esta línea, véase mi ensayo "Selomo ibn Gabirol, sabio y poeta".
} 
común a los poetas judíos que viven en Sefarad, es la que da a su escritura cierto aire de incertidumbre, propia del que se siente marginado por sus semejantes, moviéndose en consonancia con la ausencia que arrastra e intentando siempre remontarse a las fuentes. Después de tantas vacilaciones, la palabra del exilio, hermana del abismo y el silencio, es profética y se cumple en la supervivencia. Palabra de prueba, en permanente estado de alerta, que no se consume en la distancia, pues posee el sentido de un retorno a la tierra. ${ }^{2}$

La poesía ha de dar forma a la vida interior, pero tiene también que velar por la historia. Los poetas judíos que vivían en Sefarad eran conscientes de tener que existir entre esos extremos de la diáspora y la redención, con la paradoja de cantar a Yavhé en tierra extraña (“¿Cómo habíamos de cantar las canciones de Yavhé / en tierra extranjera?", dice el Salmo 137), y de esa imposibilidad surge el canto mismo. Para ellos el canto es el lugar de la pérdida ("Se canta lo que se pierde”, dirá más tarde Antonio Machado), y la preocupación del poeta será hacer del espacio en el que vive un lugar de refugio. Para los judíos que viven en al-Andalus durante el siglo XI, sobre todo entre la caída del Califato Omeya y la llegada de los almorávides, la poesía árabe clásica, más evolucionada que la preislámica de los camelleros, se convirtió en el espacio del descubrimiento. Su métrica cuantitativa, su flexibilidad rítmica y su lenguaje metafórico elevaron la escritura poética a un nivel que antes no conocíó. A diferencia de las largas casidas monorrimas, que presentan tres partes invariables: el nasib o prólogo amoroso, el rahil o relato de viaje y el madih o núcleo del poema, cada composición tiene ahora su propia forma. Lo que la poesía árabe trasvasó a Occidente, a través de al-Andalus, fue la concepción del poema como experiencia única en que la ilusión creada se convierte en la más cierta de las verdades. Semejante transformación sólo puede apreciarse a partir de la aceptación de una técnica múltiple, que sustituye la forma poética única por la forma abierta a nuevas posibilidades, combinando la melodía y la expresión. Más que por lo que dicen o por sus producciones, que en los Diwanes siguen los géneros conocidos, estos poetas lo son por su voz, cuyo acento y extensión los hace únicos. Si partimos del hecho de que el poema crea en cada momento su propia forma, cortando con lo aceptado, el poema nuevo nos hace vivir la posibilidad de una presencia por venir, pero que aún no es. Este sentido de la inminencia, característico de lo poético, se deja ver

\footnotetext{
${ }^{2}$ En cuanto a la relación del exilio con el lenguaje, que marca por entero la tradición judía, remito al estudio de Muñiz Huberman, Las raíces y las ramas, pp.81-83. Sobre el tema del exilio, especialmente visible en las obras de los judíos españoles de la Edad Media, es importante el estudio de Martín Ortega, El lugar de la palabra.
}

Medievalia 52:1, 2020, pp. 93-114 
en la escritura de Yehudah Halevi, que concibe la experiencia poética como génesis y se esfuerza más por descubrir que por imitar. El riesgo de expresar lo que el lenguaje común no puede hacer es lo que convierte a sus creaciones poéticas en experiencias totales, llenas de ilimitadas posibilidades. ${ }^{3}$

Para el poeta que ha quedado cortado con su tradición, como es el caso de los poetas judíos de la España medieval, la poesía ya no es forma, sino que se ha convertido en estado. Desde una situación de desamparo plenamente asumida, el poema se convierte en un acto de libertad que busca una realidad distinta dentro de la norma. Así, dentro de los "Poemas de amor y vino", caracterizados por el instante del placer sensible, nos encontramos con este singular poema:

Graciosa gacela, con tu hermosura me cautivaste, cruelmente me esclavizaste en tu prisión.

Desde que la ausencia se interpuso entre nosotros no he encontrado figura comparable a tu belleza.

Saboreo una roja manzana cuyo aroma es como la fragancia de tu rostro y tu atavío; tiene la misma forma de tus pechos y el color de ese rubí que asoma a tus mejillas.

En la poesía amorosa, es la mujer quien da forma a la ausencia. El tópico de la prisión, reforzado aquí por el cautiverio de los israelitas en Egipto (Éxodo, 1, 13), genera un discurso dialéctico en el que conviven la atracción y el rechazo, el deseo y la necesidad. La presencia de símbolos eróticos ("gacela", "manzana") e imágenes sensibles ("pechos", "mejillas") sirven como prueba de una realidad en la que lo femenino se declara. Porque ese amante que espera y sufre, mientras "saborea una roja manzana", que "tiene la misma forma de tus pechos y el color de tus mejillas”, está poéticamente feminizado. Precisamente, el "aroma" de la manzana, como forma de conjurar la ausencia, la distancia entre ambos, es lo que hace posible el deseo de unión amorosa. Todo viene aquí del cuerpo, que dice la emoción de la ausencia. ${ }^{4}$

\footnotetext{
${ }^{3}$ Para el análisis de los poemas de Yehudah Halevi, sigo la edición bilingüe de Sáenz-Badillos y Targarona Borrás, Poemas, más accesible que la de Brody; o la de Shirmann. En cuanto a la relación de la poesía árabe con la de los judíos de al-Andalus, además del estudio general de Pérès, Esplendor de al-Andalus, 269-278), tengo en cuenta el del poeta sirio Adonis, Poesía y poética árabes.

${ }^{4}$ La sutil analogía que se establece en este poema, pues el cautiverio de los israelitas en Egipto es similar a la prisión que padece el amante por la ausencia de la amada, es el que despierta el deseo de unión amorosa. A diferencia de las cantigas de amigo gallego-portuguesas,
} 
El valor sagrado de la pareja es la piedra fundamental de la cultura hebraica. Por eso, en todas las cópulas, siempre hay algo del Génesis. Uno de los ritos que se enraízan en ese hieros gamos es el de la Sejiná, que simboliza la relación entre Dios e Israel, proceso que se desarrolló dentro de la divinidad misma y que fue concebido por los cabalistas como una boda, según podemos ver en los escritos de Isaac Luria. El recuerdo de estas nupcias sagradas ha quedado en el ritual del sábado, que es una fiesta de esponsales, y el rescate de la Sejiná del exilio, a la que el Zohar (II, 95a) denomina "la virgen bella que carece de ojos”, sirve para expresar las esperanzas mesiánicas, a las que alude Yehudah al final de este canto de bodas:

¡Oh joven! alégrate en tu mocedad y recoge el fruto de tu gozo, tú y la joven esposa que entra en tu casa.

¡Oh amigo! Las bendiciones del Dios único

se derramen a una sobre tu cabeza.

Goce tu casa de paz sin miedos;

perezcan quienes contra ti se alcen.

$\mathrm{Al}$ acostarte no sentirás temor, y al dormir será dulce tu sueño, tú y la joven esposa.

¡Con resplandor, novio mío, cabalga y triunfa!

¡Levanta y exhibe tu belleza!

Dios hendirá el corazón de tus enemigos

y perdonará los pecados de tu juventud;

te bendecirá en las obras de tu mano y en todas tus cosechas,

tú y la joven esposa.

Recuerda a tu Roca y tu Creador

cuando te conduzca al inicio de la dicha.

en donde la joven suspira por la ausencia del amante, aquí es éste el que se lamenta por la ausencia de aquélla, dando así relevancia a lo femenino ausente. Refiriéndose a esta feminización del discurso amoroso, concentrado en el símbolo de la "gacela" o cierva, que arrastra una gran resonancia erótica desde el Cantar de los Cantares, señala Barthes: "Se sigue de ello que en todo hombre que dice la ausencia del otro, lo femenino se declara: este hombre que espera y que sufre está milagrosamente feminizado" (Fragmentos, 46). 
Aunque te alcancen las fuerzas del Destino

durará tu vigor tanto como tus días.

¡Bendito seas cuando entres y bendito cuando salgas!

tú y la joven esposa.

Adquiere tu peculio entre los íntegros

para que seas sabio en cuanto emprendas,

y esté tu casa bien fundada y construida;

que al pedir la paz Dios te responda.

En paz estará tu morada, con las piedras del campo harás alianza,

tú y la joven esposa.

¡Álcese tu gloria sin demora!

¡Que a ti te llame y escoja!

En la oscuridad de la noche tu luz

irrumpa como el alba.

¡Recibe desde el seno de la mañana, el vacío de tu juventud!

Tú y la joven esposa.

El poema se enmarca en la tradición de los himnos litúrgicos que se recitaban en la ceremonia del matrimonio. De ahí la estructura bipartita de cada una de las estrofas, según la cual hay una alternancia entre las bendiciones expresadas por el hablante y el estribillo repetido por la comunidad ("tú y la joven esposa"), puesto que el novio simboliza al Mesías y la novia al pueblo de Israel, y el lenguaje apelativo que surca el poema, según revelan los abundantes vocativos (“¡Oh joven!", “Oh amigo!”, "novio mío”) e imperativos ("Recuerda”, "Adquiere”, "Recibe”), expresiones que, por aparecer al comienzo de cada estrofa, concentran la atención del lector sobre ese ritual cabalístico del Sábado. Partiendo del hecho de que es el propio himno litúrgico el que crea su forma lingüística, observamos que el triunfo de la luz sobre las sombras en la última estrofa ("En la oscuridad de la noche tu luz / irrumpa como el alba"), además de subrayar el traslado de lo profano a lo sagrado, sirve para dar al poema una clara connotación sexual. A esta unión alude el Zohar (I, 32a): "Cuando la luz penetra la sombra ambas son fecundadas. La luz, elemento masculino, y las tinieblas, elemento femenino, se unen y forman la unidad”. Porque, al acoplarse el novio y la novia, restituyen lo diferencial a lo único, de modo que la homología de la Sejiná, que se prolongará hasta la época cristiana, lo que hace es devolvernos a la indeterminación androginal, a 
ese estado previo a la separación, que es propio tanto de la experiencia erótica como de la poética. ${ }^{5}$

Hay una diferencia notable entre los poemas panegíricos y los poemas de amistad. Mientras los primeros responden a exigencias sociales y la alabanza es genérica, los segundos expresan una relación afectiva auténtica y son menos artificiosos. Yehudah Halevi mantuvo un trato de amistad con hombres importantes de la época, pero sólo a unos pocos les abrió el interior de su persona. Uno de ellos fue el poeta Moseh ibn Ezra, con el que conservó una fidelidad extrema, tanto durante su estancia en Granada, anterior a la venida de los almorávides, como en el destierro que sufrió su amigo en la España cristiana. De él nos habla este breve poema, que nos sitúa en el sendero de lo irreductible:

¿Cómo he de hallar reposo tras tu partida?

$\mathrm{Al}$ irte tú, mi corazón se fue contigo.

Si no esperaran los corazones que tú volvieras,

la muerte nos habría llegado al separarnos.

Mira, los montes de Beter dan testimonio de que la lluvia

del cielo es tan avara como generosas mis lágrimas.

Candela de Poniente, ¡vuelve a tu Occidente!, ¡sirve

de sello para los corazones y los brazos!

¡Lengua escogida! ¿Qué tienes en común con tartamudos? 5

¿Qué hace el rocío del Hermón en el Gilboa?

Para la escritura jeroglífica egipcia, que está conectada con la Cábala más de lo que se percibe a simple vista, el corazón se representa mediante un vaso, imagen que reaparecerá en la copa mágica del Santo Grial. En su vacío mediador coinciden el fin y el comienzo, la muerte y la resurrección, de ahí que sus dos fases de concentración o sístole y relajación o diástole forman un solo latido que simboliza la integridad del cosmos. Si algo intenta proyectar la escritura poética, cuando se libera de lo inmediato, es la condición mortal de nuestro deseo, condenado a no ser jamás completamente satisfecho. En la medida en que el yo habla del otro en su propio nombre, el poema se

\footnotetext{
${ }^{5}$ Aludiendo a la relación de la boda sagrada con el ritual del Sábado, señala Scholem: “De manera rotunda se puede afirmar que el sábado es verdaderamente el día de la Cábala. En él la luz del mundo superior irrumpe en el mundo profano, donde el hombre vive los días de la semana" (La Cábala y su simbolismo, 153). En cuanto a la indeterminación androginal, cuya característica básica sería la neutralización de los opuestos, véase el ensayo de Satz, "Kábala y eros".
}

Medievalia 52:1, 2020, pp. 93-114 
convierte en una especie de autobiografía refleja en donde la intensificación de lo percibido, a través de un estado de disponibilidad como condición esencial de toda escritura, tiende a equilibrar pensamiento y expresión por medio de un lenguaje que ya no distingue entre el propio corazón y el corazón del mundo. Con estos dos recursos expresivos, la presencia del corazón como símbolo unificador y la respuesta afirmativa de las interrogaciones retóricas (“¿Cómo he de hallar reposo tras tu pérdida?”, “QQué tienes en común con tartamudos?”, “¿Qué hace el rocío del Hermón en el Gilboa?”), a los que habría que añadir la presencia del fuego como símbolo de transformación amorosa ("Candela de Poniente, ¡vuelve a tu Occidente!"), lo que busca el hablante es celebrar la amistad compartida, hacer que ésta brille como nunca en la palabra sobre el trasfondo de su pérdida. ${ }^{6}$

100 La muerte introduce la separación y de ella nace la elegía, que se construye sobre la pérdida del ser querido. Si Yehudah Halevi logró revitalizar el género panegírico mediante la introducción del lenguaje amoroso, en sus elegías no se limita a lamentarse por el desaparecido, que es lo que había hecho el género elegíaco a lo largo de la tradición clásica, sino que dialoga con él para mantenerlo vivo en el recuerdo. En este sentido, tal vez su mayor singularidad consista en haber incorporado a sus poemas fúnebres el esquema de la balada, con su mezcla de lirismo y dramaticidad, creando un mundo imaginario en el que los personajes van descubriendo lo que sienten a través de sus propias palabras, como sucede en este lamento entre madre e hija:

¡Ay, hija mía! ¿Has olvidado tu morada

al partir hacia el se'ol los que llevan tu féretro?

Nada tuyo tengo, sólo tu recuerdo.

Me compadezco del polvo de tu tumba

cuando me vuelvo a preguntar por ti y no estás,

porque la muerte nos separa.

¡Hija nacida de la alcoba de tu madre!

¿Cómo viviré si de mi alma procede su figura?

\footnotetext{
${ }^{6}$ Para una visión del corazón como morada de la imaginación y del lenguaje, que forma parte de una psicología arquetípica ya iniciada por Jung, véase el estudio de Hillman, El pensamiento del corazón. En cuanto a la petición del poeta a su amigo para que éste vuelva del destierro, a la que Moseh ibn Ezra le responde con otro poema similar, lo cual revela el grado de amistad compartida entre estos poetas, véase la antología de Sáenz-Badillos y Targarona, Poetas hebreos, 164 y ss.
} 
Hiendo las rocas al ver su semblante, cómo se torna blanco de su hermosura.

Allí en el se’ol veré, el día de su boda, cómo levanta su dosel con terrones y lo dulces que le son las glebas de su tumba.

Siento amargura, ¡hija mía!, amargura por tu falta, porque la muerte nos separa.

¡Rosa cortada antes de tiempo cuya imagen es filacteria entre mis ojos!

¡Cómo pueden verterse lágrimas cual ríos!

¡Cómo ocultarse en el seno del polvo la hija de la Osa!

¡Cómo cubrirse el sol de gusanos,

y ser las sogas del se'ol turbantes sobre su cabeza!

¡Ay, hija mía!, no hay sentencia de juez para sanarte, porque la muerte nos separa.

Clamor de parturienta oigo a la madre sin hijos, cálmala, ya que siente amargura su alma, porque se encaramó la muerte a sus balcones; se cercenaron sus entrañas, emigró su alma y se trocó su alegría en alarido, al arrancarle la cepa plantada en el corazón. ¿Qué gritaré, hija mía? tu oído es incircunciso $y$ tu lengua no tiene palabras para responderme porque la muerte nos separa.

¡Ay, hija mía, mucho me has afligido!

¡Ay, madre mía, ay de mí que me has dado a luz! mas hoy, ¡cómo me has aborrecido!

Me has criado para el primogénito de la muerte: al llegarle el momento a mi alma me despediste, me coronaste con corona de polvo y bajo el dosel de la muerte me sentaste, contra tu voluntad, en verdad, no por tu gusto, porque la muerte nos separa.

El que decreta sin que se anulen sus mandatos, haga caer tus cuerdas en lugares placenteros. 
El que es tan grande que no se irrita con sus ejércitos

tenga piedad, haga cesar sus plagas

y consuele el corazón de sus desgracias.

Que te resucite con el vacío de sus lluvias el último día, y consolide tu diestra con su justa mano

porque la muerte nos separa.

El poeta no habla aquí de la muerte directamente, sino del espacio discursivo que ella rige, lo cual nos lleva a tenerla presente sin ocultarla, puesto que pensar en la muerte es pensar en lo otro que somos. Por eso, la fórmula del juramento contenida en el estribillo que da sentido al poema ("porque la muerte nos separa"), que alude a la relación de Yavhé con su pueblo ("Donde te mueras moriré / y allí seré enterrada. / Que Yavhé me de este mal / y añada este otro todavía / si no es tan sólo la muerte / lo que nos ha de separar", Rut, I, 17), no sólo sirve para mantener unidos dos mundos distintos por medio del diálogo, puesto que la madre se dirige a su hija muerta como si estuviera presente, sino también para expresar una poética sombría de la caducidad (“¡Rosa cortada antes de tiempo”), que ha privado a la hija de su función materna. En realidad, el juramento que hace la madre de seguir unida a su hija en el recuerdo, reforzado por la imagen de la "filacteria", símbolo de la unión entre Yavhé e Israel, no hace más que expresar el deseo de reconciliación de la hija con su madre, de prolongar la vida más allá de la muerte ("Que te resucite con el vacío de sus lluvias el último día”), donde la lluvia aparece como símbolo de fertilidad, pues sólo consintiendo en la muerte se puede acceder a una forma superior de vida, alcanzar la plena feminidad. ${ }^{7}$

La tradición debe ser entendida no sólo como recepción y transmisión sino también como recreación y revelación del sentido. Dado que para el judío el texto está abierto a la infinitud de interpretaciones posibles, la exigencia de un pensamiento en marcha, que no puede ser unificado ni totalizado, es lo que desencadena la posibilidad de ser otro ("Sólo tienen valor los pensamientos que surgen cuando caminamos", dice Nietzsche). Esa es la función de los géneros breves como el aforismo y el fragmento, portadores de un cambio de sensibilidad y que proponen un punto de reflexión sobre la suspensión del mundo real. Algunas de las reflexiones que Yehudah Halevi nos deja en sus poemas de madurez, enraizadas en la identificación del poeta con su pueblo,

${ }^{7}$ En cuanto al tópico de la muerte asociada a la separación dentro del diván de Yehudah Halevi, véase el estudio de Salvatierra Ossorio, La muerte, 95-138. Respecto a las formas de lo elegíaco, remito al ensayo de Navarro Peiró, "Lo judío y lo árabe”.

Medievalia 52:1, 2020, pp. 93-114 
utilizan las fórmulas del género sapiencial para expresar la cuestión contra el Destino, contra un proyecto establecido de antemano, rebelión que nos hace volver al momento de la primera alianza entre Sión y su Creador:

Mi alma por la casa paterna suspira y se consume, hasta en sueños a contemplarla asciende.

Asciende sin hallar remedio, pues el sueño no sana al alma que al despertar se siente enferma. Se siente enferma cuando no puede implorar a Aquél sin cuya gloria y esplendor se agosta.

Se agosta pero resurgirá, se fatiga mas hallará contento, pues no se sumió en el caos cuando partió al exilio. Partió al exilio y abrió las compuertas del manantial, mas sus ojos en las aguas profundas quedaron fijos.

Quedaron fijos en el poste, e hizo promesa y juramento de no abandonar nunca la sabiduría.

Si en las antiguas tradiciones "el poste" o escala funciona como arquetipo ejemplar del Árbol del Mundo, asegurando la comunicación entre el Cielo y la Tierra, como la escala que Jacob vio en sueños ("Y los ángeles de Dios subían y bajaban por esta escala”, Génesis, 28,11), así también la sabiduría de Dios, su vida secreta proyectada en la Torá, es la que permite al hombre experimentado superar la condición temporal del exilio y volver de nuevo al origen de "la casa paterna", símbolo del Santuario de Sión, donde habita la divinidad. Como sucede en el género sapiencial, donde la lengua sintetiza pensamiento y palabra, el hecho de que cada verso comience repitiendo la última palabra del verso anterior, lo que en retórica se conoce como complexión o sucesión de epanadiplosis, nos hace ver que el hablante, igual que el salmista, se interesa por la interioridad humana ("Mi alma") y busca su salvación en la relación con Dios ("Aquél”), apelando a la experiencia de la tradición y pasando de la meditación a la contemplación. El templo de Dios o "casa paterna" abre una perspectiva hacia el futuro ("En el santuario de Dios dirijo la mirada al final sobrepasando lo presente”, dice San Agustín), de manera que lo que no da el sueño, imagen de una vida confusa en estado naciente, lo proporciona la contemplación, que ofrece al hombre un conocimiento nuevo y superior. Lo que en ella descubre el poeta no es una información de sucesos, sino una presencia personal, la posibilidad de sentir cerca al Otro. Al penetrar en lo íntimo de su ser, lo que descubre el salmista, por la intensidad de su 
experiencia de Dios, es que su palabra trasciende cielo y tierra, abre camino a una intuición profunda de la realidad. ${ }^{8}$

De la poesía compuesta por los judíos en España, entre el siglo x y el siglo $\mathrm{XV}$, destacan dos modalidades básicas: la lírica secular, de carácter profano e individual, y la sinagogal, destinada al servicio litúrgico y a ser recitada por la comunidad en la sinagoga. Dentro de ésta, los maestros rabínicos atribuyeron al Cantar de los Cantares un sentido simbólico, según el cual el amado se interpretó como el Dios de Israel; la paloma como expresión del pueblo de Israel en el destierro; y el amor entre ambos como el pacto establecido entre Dios y su pueblo. Así pues, en los poemas que Yehudah Halevi compone en torno a este símbolo matriz de la paloma, conviven casi siempre la situación de desamparo y la esperanza de liberación. Veamos uno de los más conocidos:

Mi paloma de noche vaga por las calles, va buscando al que ama.

Déjala, que eleve su voz entre sollozos, pues su mal es grave lo mismo que su culpa.

Ha contado ya mis años y no se desunce su yugo.

La populosa, cual sin hijos, permanece turbada y calcula los plazos.

Me asemejo al pelícano errante del desierto.

Soy ave solitaria en el tejado.

Gimo, pues con el llanto me conforto.

Mis lágrimas de la mejilla no se secan, fluyen por tu ciudad derruida.

¡Que se consuele el corazón tronchado por las penas al inflamarse recordando los tiempos que han pasado! ¿Quién luchará con los juicios de Dios que predominan? Mi esperanza en ti no se ha visto defraudada; se retrasa, ¡mas tu pacto no es engaño!

\footnotetext{
${ }^{8}$ En los Salmos se cumple el ciclo de la palabra pronunciada, contemplada y revelada. Sobre la dimensión escatológica del género sapiencial, que es para ser cantado a solas, remito al estudio de Alonso Schökel, Treinta salmos. En cuanto al símbolo axial del poste o "escala", relacionado a su vez con el Árbol del Mundo, véase el trabajo de Eliade, Imágenes y símbolos, 44-50.
} 
No es difícil percibir en este poema una estructura dialógica, característica del estilo sapiencial, como expresión del drama interno, que padece el hablante, entre el desaliento y la esperanza. La búsqueda inicial, que alude al Cantar de los Cantares ("Me levanto y vago por la ciudad / Por los mercados y encrucijadas / Busco a mi amor”, 3,2), símbolo de la libertad de deseo sexual, se ve complementada al final por la confianza en la verdad del pacto ("imas tu pacto no es engaño!”), que anuda las relaciones entre Dios y su pueblo. Entre ambos extremos, un lenguaje exclamativo, en el que las alusiones a la destrucción del templo ("Ha contado ya mis años"), a la venida del Mesías ("calcula los plazos"), y la comparación con "al pelícano errante del desierto”, que sustituye al ave fénix como símbolo de muerte y resurrección, hacen de "la paloma” una figura de la Presencia divina, que se revela en la desnudez extrema de la metáfora erótica. Porque si algo muestra esta imagen personificada es su dilatación o condición expansiva ("ensancha mi corazón encogido y sácame de mis angustias", dice el Salmo, 25, 17), la potencialidad de una palabra destinada a superar cualquier resistencia, incluido el destierro, manifestando un único amor, por el cual el hombre alaba y reconoce a Dios. ${ }^{9}$

El monte Sión, lugar donde se ha levantado el templo de Jerusalén, atrae como centro en el que se cumplen los votos ("Oh Dios, tú mereces un himno en Sión, / y a ti se te cumplen los votos / porque tú escuchas las súplicas”, Salmo, 65, 2-4). Hay que sentir esta experiencia numinosa de la divinidad, mysterium fascinans et tremendum, para expresar un contenido máximo con una forma mínima. En ese profundo sentimiento de nostalgia, que tiende a la tierra prometida como plenitud, se situarían los “poemas de Sión”, en los que la poesía secular sigue los esquemas de la poesía litúrgica y cuya estructura evidencia tres instancias básicas: el pasado feliz, el presente angustioso y el futuro esperanzado. Ejemplo de esta forma compositiva sería el poema “Sión ¿no me preguntas?”, repetido de generación en generación y donde la fusión de diversos géneros, especialmente la poesía amorosa y la elegía secular, sirve para personalizar lo abstracto, presentando en un mismo plano mundos distintos y alejados, Palestina y Sefarad, y echando de menos lo que antes tenía el poeta y ahora no tiene. Asílo vemos en esta breve composición:

\footnotetext{
${ }^{9}$ Para las dos modalidades señaladas, poesía secular y poesía sinagogal, tengo en cuenta las ediciones de Millás Vallicrosa, La poesía sagrada hebraicoespañola, y Pérez-Castro, Poesía secular hispano-hebrea. En cuanto a las diversas interpretaciones sobre el Cantar de los Cantares, la carnal entre hombre y mujer, según revela la lectura inmediata del texto; la que celebra el amor de Yavhé por su pueblo, de acuerdo con la tradición hebrea; y la que se centra en el amor del alma y su Dios, como quiso San Juan de la Cruz y la tradición mística, remito al ensayo de Ceronetti, El Cantar de los Cantares.
}

Medievalia 52:1, 2020, pp. 93-114 
Mi corazón está en Oriente, y yo en los confines de Occidente.

¿Cómo gustar de los manjares y disfrutarlos?

¿Cómo cumplir mis votos y mis promesas, si sigue

Sión bajo el poder de 'Edom y yo sometido a los árabes?

Me parecerá tan fácil abandonar todo el bien de Sefarad,

como preciado contemplar las ruinas del Santuario destruido.

Para los judíos de la España medieval, Oriente designa Palestina, la tierra de los antepasados, y Occidente su situación en al-Andalus, donde se ven obligados a vivir bajo el Islam. Lo que intenta aquí el poeta, mediante el símbolo unificador del corazón y la correspondencia simbólica entre Oriente y Occidente, Sión y Arabia, Sefarad y Jerusalén, es situar a un mismo nivel el pasado y el presente, hacer que la experiencia amarga del exilio se convierta en un bien soñado. Esos lugares quedan vinculados entre sí al ocupar posiciones equivalentes por medio del paralelismo. E igual sucede con las oraciones interrogativas, intensificadas anafóricamente, o con los casos de aliteración y juegos de palabras ("gustar de los manjares"). Como es sabido, el tópico de que Occidente siente nostalgia de Oriente es anterior a Halevi, pues ya lo expresa el emir Abderramán I al recordar las palmeras de Siria en la mezquita de Córdoba, pero la diferencia está en que uno habla con añoranza de lo perdido, de lo que tuvo y ya no tiene, y el otro lo hace con la esperanza puesta en aquello que desconoce. Al expresar su nostalgia de Sión como si estuviera enamorado de una mujer ausente, pues Sión se presenta como la dueña del corazón del poeta, lo que hace éste es convertir esa añoranza en un proceso personal y espiritual. De este modo, Sefarad deja de ser un lugar concreto para designar la patria como nación, sentimiento siempre presente en el alma judía. Una vez más el exilio se revela como el lugar en que el poeta vuelve a encontrar su autonomía, su disponibilidad. ${ }^{10}$

La poesía judía más importante del período áureo era la poesía religiosa, tal vez por ser la mejor aceptada y recitada por todos en la sinagoga, pues la poesía profana se inspiraba en la tradición poética árabe. Desde el año 1090, con la llegada de los almorávides al sur de Sefarad, la vida no fue fácil en las

${ }^{10}$ La originalidad de Yehudah Halevi hay que verla en su capacidad para refundir géneros conocidos. En este sentido, merece destacarse la fuerza de sus imágenes para plasmar sentimientos abstractos. Tal hecho ha sido subrayado por Pagis en su estudio, Secular Poetry, 6470. Obra traducida por la Universidad de Granada en 1994. En cuanto a la comparación de la poesía de Abderramán I con la de Yehudah Halevi, véase el ensayo conjunto de Barkai y Doron, "Mi corazón en el Oriente". 
aljamas. La conciencia de tener que vivir entre la espada y la pared, entre musulmanes y cristianos, junto con los cálculos fallidos de la anunciada venida del Mesías en 1130, con el que se acabaría el islamismo en España, son experiencias que desencadenan la composición de los poemas siónidas, en los que se combinan el dolor ante una situación adversa y el amor por el regreso a la tierra de sus mayores. Dentro de ellos, ocupan un punto clave los "Poemas del mar", en donde el motivo del viaje, la sensación de estar en camino, sirve de prueba iniciática en la que el poeta se va desligando de su vida pasada para realizar su deseo de morir. La lección del mar, signo de la frontera entre la vida y la muerte, es también poética, pues en ella la experiencia de la renuncia es el precio por la libertad. De ahí que el navegante no tema en medio de la tormenta, consciente de que tras la tempestad viene la calma de la contemplación:

¿Ha llegado el diluvio dejando asolado el universo?

No se divisa tierra firme,

no hay hombres, ni animales ni aves,

¿perecieron todos? ¿murieron en tormento?

Sentiría alivio al ver un monte u hondonada;

una tierra yerma haría mis delicias.

Miro a todos los lados, y no hay nada

sólo agua, cielo, un Arca,

y Leviatán haciendo hervir las simas de los mares,

tanto, que creo se parece el abismo al cabello cano.

El seno de los mares quiere ocultar la nave,

como si fuera en manos de las aguas algo robado.

El mar está furioso, mas mi alma se regocija, porque

se acerca al Santuario de su Dios.

Como es propio de los poemas siónidas, hay aquí una situación de contraste entre la falta de esperanza y la alegría de estar próximo a la Tierra de promisión, con la que finaliza el poema. La imagen del Arca, que alude al Arca de Noé como símbolo de salvación, y la figura de Leviatán, monstruo marino que evoca las fuerzas primitivas de lo inconsciente, hostiles al poder de Dios (Job, 41, 23), y cuya semejanza con la muerte resulta evidente ("se parece el abismo al cabello cano"), hacen del agua marina un rito de paso o "salto en lo desconocido", una ensoñación transformadora que participa de una dinámica del universo. Extraña representación de la tempestad, donde la correspondencia entre los movimientos del océano y la conciencia de un 
alma angustiada hace posible la comunicación íntima con ese proceso de destrucción creadora, simbolizado por el movimiento de las olas. Como dice Novalis, "La tempestad favorece la pasión”, y lo que hacen estas imágenes con su sentido realista ("como si fuera en manos de las aguas algo robado"), es probar que la gravedad poética se profundiza con el agua, que en el ámbito de la psicología dinámica es más importante lo imaginado que lo real. ${ }^{11}$

En su viaje hacia Jerusalén, Yehudah Halevi hizo de su estancia en Egipto un alto en el camino, un punto intermedio, cuyo recuerdo va ligado a la historia del pueblo judío. No deja de ser sorprendente que en estos "Poemas de Egipto” no se recuerde la esclavitud de Israel, anterior a su liberación, y sí en cambio a Egipto como lugar donde el pueblo recibió la revelación de Dios. Si el propósito del lenguaje religioso consiste en afirmar lo trascendente como real, las frecuentes indicaciones de lugar que aparecen en estos poemas nos hacen ver el carácter iluminador de la palabra poética, cuya súbita percepción de lo real es la que nos lleva a penetrar su trascendencia. Y lo mismo que la zarza que arde sin consumirse aparece como una revelación del Nombre divino (Éxodo, 3), así también la palabra poética, sin dejar de ser temporal, es al mismo tiempo una imagen de lo eterno. La fidelidad a esa palabra creadora, que Dios concede al hombre y a su vez éste da a la realidad, es lo que constituye la preocupación constante del decir personal de Yehudah Halevi, según vemos en este poema de alabanza:

¡Loa a Egipto sobre todo otro lugar!:

Allí se oyó por vez primera la palabra de Dios.

Allí se plantó la viña escogida, y fueron sus racimos los predilectos.

Allí nacieron los enviados de Dios, que llevaron sus mensajes como del novio a la novia.

Allí descendió la gloria divina y marchó en columna de fuego, nube y cobertura.

Allí se realizó el sacrificio del Señor, se dio la sangre de la Alianza y llegó la liberación. Allí está el lugar donde Moisés estuvo suplicante, ¡no hay lugar comparable para la oración!

\footnotetext{
${ }^{11}$ Resulta claro que este viaje del poeta por el mar forma parte de un proceso iniciático de la muerte a la vida, característico de los ritos de paso. En este sentido, véase el estudio de van Gennep, Los ritos de paso. En cuanto al simbolismo de las aguas profundas, vinculado a la ensoñación de la muerte, véase el trabajo de Bachelard, El agua y los sueños, 74-110.
} 
Israel era con Egipto y Babilonia

la tercera, y había calzada entre ellas.

Hubo en su interior un altar del Señor,

para ensalzar su nombre sobre toda loanza,

y prodigios y señales, y el Nombre

cuya gloriosa mención llena el Universo.

De los ríos del Edén procede su Río;

la hermosura de su país con el jardín del Edén se equipara.

La hemos escudriñado, y está bien, mas mi corazón

se resiste a los que curan con liviandad.

Yo sé que allí descendió el Señor

como huésped a la sombra de la encina y el terebinto;

pero en Jerusalén y en Sión fue ciudadano.

Allí está la Torá, allí la Grandeza.

El lugar del juicio y la misericordia están allí.

Allí obtendrá el hombre el premio de sus obras.

Se llama monte de Dios, monte de su heredad;

lo separó bendiciéndolo como el pan del sábado.

El que desde su santidad desciende hacia Babel

o Egipto...

pero el que desde cualquier otro país asciende

a ellas, tendrá un excelso mérito.

¿Por qué se mofan de mí los burlones?

¿Por qué estoy todo el tiempo en su boca?

A aquéllos que creen en la religión de Dios,

he de juzgar según la ley de Israel;

mas una barrera me separa de los que no creen.

¡No hay entre nosotros condominio!

Dentro de los cánones del género encomiástico, donde la palabra se convierte en interpretación, el lenguaje no funciona sólo como recurso retórico, sino como un ejercicio de celebración que trata de reproducir la armonía original entre Dios y el hombre, en un círculo revelador que parte de Dios, se realiza en el hombre y vuelve a Dios mediante la celebración litúrgica. Este proceso de descenso ("El que desde su santidad desciende hacia Babel / o Egipto") y ascenso ("pero el que desde cualquier otro lugar asciende / a ellas") hace de Egipto el lugar de la palabra, lo cual viene subrayado por una serie de recursos expresivos, como la intensificación anafórica del adverbio de lugar con valor temporal ("Alli”"), la viña como metáfora del pueblo de Israel 
("Allí se plantó la viña escogida”), la semejanza del Nilo con el Paraíso ("De los ríos del Edén procede su Río") y la serie de alusiones bíblicas, como "el pan del sábado", fiesta de los esponsales, que tienden a hacer de Egipto un lugar sagrado, si bien temporal, puesto que en él Dios sólo se manifiesta "como huésped”, donde lo real y lo espiritual son uno. De ahí que vaya asociado al Nombre divino ("cuya gloriosa mención llena el Universo"), porque el lugar es el punto o el centro sobre el que se circunscribe el mundo. Esta vinculación al lugar, propia de lo humano, es lo que convierte a la palabra en figura del cosmos, en sueño y expresión de eternidad. ${ }^{12}$

En la historia del judaísmo la Tradición constituye un organismo vivo, cuyo despliegue afecta tanto a la revelación de la palabra divina como a su transmisión. Precisamente porque la tradición capta la relación dialéctica en110 tre el oyente y los nombres del Dios, su voz, al expresarse en el doble lenguaje del dar y el recibir, no se interrumpe, sino que se presenta dentro de un proceso inagotablemente rico, que tiende a retornar a esa unidad de lo primigenio desde la multiplicidad. Tal vez por eso el Mesías aparece como el fruto de Israel en medio de los pueblos, que proporciona el fundamento para la visión del futuro, según vemos en el "Discurso cuarto" del Cuzary, obra compuesta por Yehudah Halevi en sus años finales y que sólo puede ser entendida desde una perspectiva mesiánica:

como la Sapiencia que ay en el grano de la simiente, que cae en la tierra, y aparentemente le parecerá al que lo viere, que se mudará y convertirá en tierra, agua, y estiércol, sin quedar ninguna señal de él: pero el grano es que muda la tierra y la agua en su naturaleza, y de grado en grado convierte los elementos a la semejanza de su substancia, y echa su corteza y sus hojas; y quando se purificare y fuere apto para resedir en él aquella cosa y la forma de la primera simiente, hará fruto el tal árbol, semejante al fruto de la simiente de que es.

La parábola del grano, empleada en el evangelio (Mt. 14, 31), permite entender la realidad del exilio de manera inmediata, como signo de la condición humana y de la posición singular de Israel en medio de todas las naciones. Porque el exiliado, al hallarse dividido entre su origen y su visión histórica, se presenta como un ser trágico que reclama su identidad perdida, sostenido en el límite entre vida y muerte. En este sentido, la semilla aparece

${ }^{12}$ Este valor religioso de la expresión verbal, que fue preocupación vital y constante del poeta tudelano, ha sido subrayado por Fleischer, "New Poems"; y Doron, "Los poemas de Egipto”. 
como metáfora original en la que conviven la caída y la resurrección. Dado que el estar sin patria ni casa le hace andar fuera de sí, en permanente vigilancia y tensión, el exiliado es el que más se asemeja "al grano de la simiente", que ha dejado de ser todo para seguir siendo en cada nueva metamorfosis ("pero el grano es que muda la tierra y la agua en su naturaleza"), siendo esa situación de desamparo, de quedarse a la intemperie, la que lo mantiene vivo a lo largo del tiempo, convirtiéndolo en eje de la historia. La soledad se hace así insalvable distancia y su palabra, siempre al borde del nacer, permite que la vida siga, sin quedar estancada en las aguas del olvido. Por eso, más que superviviente de una situación adversa que él no ha buscado, el exiliado aparece como ser naciente, como el hombre que se ha perdido y que, mediante el sacrificio, se dispone a dar lo mejor de sí mismo. Porque la cuestión es ir deshaciendo infiernos, salir de la desposesión en que uno ha estado para vivir una vida mejor, ya que, según Juan de la Cruz, la esperanza purifica la memoria. Oscura gestación la del exilio, que reclama la libertad que se cumple en la obediencia y que, en virtud de esa presencia de lo eterno en lo humano, propia de la revelación, no puede ser más que fundadora. Lejos de reducirse a una etapa histórica, el exilio se revela como una experiencia estético-metafísica, que surge del esfuerzo con el que uno sale de sí mismo a la búsqueda del otro. ${ }^{13}$

En los escritos de Yehudah Halevi el exilio forma parte de una actitud mesiánica, que concibe la salvación como un proceso en el escenario de la historia. Lo realmente nuevo del mensaje mesiánico, presente en el judaísmo medieval, no es su visión apocalíptica, que representa tan sólo la fachada exterior, sino la recuperación de lo perdido en circunstancias históricas muy concretas, hecho que no afecta a un individuo como tal, sino a la humanidad en su conjunto. Dado que el tiempo mesiánico es imprevisible, pues la llegada del Mesías puede producirse en cualquier día (“Tres llegan inesperados: el Mesías, el hallazgo y el escorpión”, se dice en el tratado talmúdico Snahedin, 97, 1), la posibilidad de salvación de un Mesías oculto se empareja imaginativamente con el carácter súbito de la revelación poética, que llega de pronto, sin anunciarse y cuando menos se la espera. En este sentido, no puede

\footnotetext{
${ }^{13}$ Refiriéndose a la fidelidad de los judíos a su religión, tal vez como forma de permanecer unido en medio de la adversidad, señala Millás Vallicrosa: "La religión de Israel es como el grano que se ha sembrado en la tierra, que parece que se consume y altera en medio de la tierra, el agua y el humus, pero que, en rigor, lo que hace es convertir estos elementos en su propia substancia, lo que se comprueba al tiempo de la germinación" (Yehudá Ha-Leví como poeta, 153). En cuanto al significado constructivo de la tradición, véase Scholem, Conceptos básicos, 75-98.
}

Medievalia 52:1, 2020, pp. 93-114 
sorprender que, en el contexto apocalíptico del siglo XII, en torno a 1130, el exilio se perciba como un reino de Dios sobre la tierra y se revista de rasgos utópicos. Para los judíos de Sefarad, que tienen conciencia del abismo entre la miserable realidad histórica y el sueño de plenitud salvadora, la experiencia del exilio, que se mueve en los extremos de la expulsión del paraíso y el naufragio en la historia, aspira a una reincorporación de la armonía cósmica, según vemos en el mito luriano de la "rotura de las tres vasijas". En esta anticipación de la plenitud final, ya que el exiliado se presenta como una voz enajenada que clama por ser diferente dentro de la historia, se contiene en germen el dinamismo inmanente del exilio, según el cual éste aparece como expresión de un estado interior del mundo y del hombre, de su conciencia individual.

La figura mediadora del Mesías, que por sí misma concentra la plenitud 112 de la salvación, reúne los dos aspectos contrapuestos, el catastrófico y el utópico, a lo largo del judaísmo, que conserva lo inconfundible de su radical incertidumbre. A diferencia del mesianismo cristiano, en donde todo gira en torno a la persona de Cristo, en el judaísmo la duplicidad de la figura del Mesías, que ofrece un desdoblamiento en un Mesías de la casa de David y un Mesías de la casa de Yosef, vuelve a poner de relieve la tensión existente entre las dos formas de autoridad religiosa, la rabínica o conservadora y la mesiánica o utópica. En el caso de Yehudah Halevi, bastaría un poema como el "Himno de la Creación", tan próximo a la "Corona real" de Gabirol y en el que se revela la posibilidad de la palabra para decir el Nombre divino desde una dolorosa expectativa mesiánica (“La palabra de quién te ha contenido? / ¿Y la lengua de quién te ha comprendido?”, vv. 7-8), para darnos cuenta de que el exilio judío, cuya experiencia tiene lugar en un mundo todavía no salvado, responde a una visión incompleta, pues desde la caída de Adán, el mundo ya no está regido por el árbol de la vida, sino por el árbol del conocimiento, a una restauración del estado paradisíaco, que implica un tiempo sin tiempo, anterior al ser humano y cuya característica sería la suspensión de un estado contemplativo. Paraíso perdido y buscado, hacia el que avanzamos a tientas, sabiendo que su recuperación es irrealizable ("como alguien que avanzara sobre un puente ya hundido”, dice Musil en Carta a Franz Blei, del 2 de agosto de 1933). Y sin embargo, en esa navegación imposible entre dos orillas opuestas, que no puede concluir sino con su propio naufragio, radica la aporía que desasosiega al exiliado, que se limita a vagar siempre entre posibilidades, su gran poder de atracción. ${ }^{14}$

${ }^{14} \mathrm{El}$ exiliado está inserto en la tradición de la que forma parte, bien para continuarla o bien para modificarla. Aludiendo a esa relación dialéctica en que se desarrolla la revelación, 
En una poesía en alabanza de Joseph ibn Migash, discípulo predilecto de Al-Fasi y cuya sabiduría fue alabada por el propio Maimónides, dice Jehudah Halevi: "Y ciertamente hoy he sabido que en medio de nosotros está el Señor". Ahí radica precisamente la singularidad del exilio, en sentirse uno mismo como eje de la historia en medio de los demás, en habitar el corazón de la realidad. Pues el exiliado, el que está fuera de su centro vital, trata de penetrar en su propia alma, que es una con el alma del mundo. Vive solo con la memoria del lugar al que pertenece, como esa llave que llevaron consigo los judíos sefardíes al partir de España, con la esperanza de volver otra vez a una tierra que estos poetas identificaron con el paraíso. Porque la poesía participa ella misma de este doble movimiento de expulsión y retorno, de salida de lo habitual y de regreso al origen, al punto único en que despierta el sentido de la vida.

\section{BIBLIOGRAFÍA}

Adonis, Poesía y poética árabes, Madrid: Ediciones del Oriente y el Mediterráneo, 1977.

Alonso Schökel, L., Treinta salmos: poesía y oración, Madrid: Ediciones Cristiandad, 1981.

Bachelard, G., El agua y los sueños, México: Fondo de Cultura Económica, 1978.

BARKAI, R. y A. Doron, "Mi corazón en el Oriente y yo lejos de la tierra de las palmeras", Helmántica, 32:97-98, 1981, 239-252.

BARthes, R., Fragmentos de un discurso amoroso, Madrid: Siglo XXI, 1982.

Brody, H., Abu-l-Hasan Jehuda Hallevi, Berlin: 1894-1930, 4 vols.

CACCIARI, M., Paraíso y naufragio, Madrid: Abada Editores, 2005.

Ceronetri, G., El Cantar de los Cantares, Barcelona: Acantilado, 2001 (El Acantilado, 41).

Doron, A., "Los poemas de Egipto de Yehuda ha-Levi", en Actas del II Congreso Internacional Encuentro de las tres culturas (Toledo, 3-6 de octubre 1983), Toledo: Ayuntamiento de Toledo, 1985, 117-123.

Eliade, M., Imágenes y símbolos, Madrid: Taurus, 1979.

señala Scholem: "Precisamente porque capta lo vivo de la palabra, lo recibe y desarrolla, tiene la Tradición fuerza suficiente para que las contradicciones y tensiones no sean destructoras, antes bien adquieran un significado constructivo e incitador" (Conceptos básicos, 92). En cuanto a la relación entre la expulsión del paraíso y el naufragio en la historia, que siempre arrastra el exiliado, véase el estudio de Cacciari, Paraíso y naufragio.

Medievalia 52:1, 2020, pp. 93-114 
Fleischer, E., "New Poems and Poetical Fragments by Yehudah Halevy”, Jerusalem Studies in Hebrew Literatura, 13, 1992, 65-94.

Gennep, A. van, Los ritos de paso, Madrid: Taurus, 1986.

Hillman, J., El pensamiento del corazón, Madrid: Siruela, 1999.

López Castro, A., "Selomo ibn Gabirol, sabio y poeta”, Boletín Bibliográfico de la Asociación Hispánica de Literatura Medieval, 2, 1988, 401-406.

Martín Ortega, E., El lugar de la palabra, Palencia: Cálamo, 2013.

Millás Vallicrosa, J. Ma., La poesía sagrada hebraicoespañola, Madrid: Consejo Superior de Investigaciones Científicas, 1940.

Millás Vallicrosa, J. Ma., Literatura hebraicoespañola, 3ª ed., Barcelona: Labor, 1973.

Millás Vallicrosa, J. Ma., Yehudá Ha-Leví como poeta y apologista, Madrid-Barcelona: Consejo Superior de Investigaciones Científicas, 1947.

Muñiz Huberman, A., Las raíces y las ramas. Fuentes y derivaciones de la Cábala hispanohebrea, México: Fondo de Cultura Económica, 1993.

Navarro Peiró, Á., "Lo judío y lo árabe en la poesía secular hispano-hebrea: las elegías”, en J. Peláez del Rosal (ed.), Los judíos y Lucena. Historia, pensamiento y poesía, Córdoba: El Almendro, 1988, 85-101.

PAgIs, D., Secular Poetry and Poetic Theory: Moses Ibn Ezra and His Contemporaries, Jerusalén: 1970.

PÉrès, H., Esplendor de al-Andalus, Madrid: Hiperión, 1983.

Pérez-Castro, F., Poesía secular hispano-hebrea, Madrid: Consejo Superior de Investigaciones Científicas, 1989.

SÁenz-Badillos, Á. y J. Targarona Borrás, Poemas, Madrid: Alfaguara, 1994.

Sáenz-Badillos, A. y J. Targarona Borrás, Poetas hebreos de al-Andalus (siglos X-XII), Córdoba: El Almendro, 1988.

SAlvatierra Ossorio, A., La muerte, el destino y la enfermedad en la obra poética de Y. Ha-Levi y S. Ibn Gabirol, Granada: Universidad de Granada, 1994.

SAtz, M., “Kábala y eros”, en M. Satz, Árbol verbal. Nueve notas en torno a la Kábala, Madrid: Altalena, 1983, 47-58.

Shirmann, H., Ha-sirah ha-ivrit bi-Sefarad u-be, Provence, Jerusalén: 1954, 2 vols.

Scholem, G., Conceptos básicos del judaísmo: Dios, creación, revelación, tradición, salvación, Madrid: Trotta, 1998.

Scholem, G., La Cábala y su simbolismo, México: Siglo XXI, 1978. 